\title{
Improving the Methodological Basis for Assessing Regulatory Policy in the Agricultural Sector: Areas for Further Research
}

\author{
${ }^{1}$ Natalia Shibaeva*, ${ }^{2}$ Tetiana Baban \\ ${ }^{1,2}$ Department of Economic and Marketing, Kharkiv Petro Vasylenko National Technical University \\ of Agriculture, Kharkiv, Ukraine
}

\begin{abstract}
The agricultural sector occupies an important place in post-industrial society. The agricultural sector is associated with such sustainable development goals as economic growth, food security, rational use of resources, increasing the incomes, rural development and preserving the environment.

An effective state policy is able to ensure the advancement of the agriculture towards achieving the sustainable development goals. But the formation of state policy should be preceded by a comprehensive assessment of the effectiveness of state measures in previous periods.

The article proposes an improving the author's methodology of comprehensive assessment of the effectiveness of state policy of Ukrainian agriculture. Suggestions for improvement are to strengthen the environmental and social components of assessing the progress of sustainable development goals. The strengthening of the environmental component of the assessment of the progress of sustainable development goals was carried out through the inclusion in the system of assessment of protection indicators and restoration of ecosystems in the process of their use in the agriculture. The strengthening of the social component was achieved through the inclusion in the cost estimation system of the State programs to support housing in rural areas, social investments and own resources of local communities to create a comfortable environment.

Approbation of the improved methodology of comprehensive assessment of the effectiveness of state policy in the agriculture was conducted on the example of the agricultural sector of Ukraine in 2010, 20162018. The comprehensive assessment showed slow progress in the effectiveness of regulatory policy in agricultural sector of Ukraine in 2010, 2016-2018 and revealed the backlog of social and environmental indicators in the approach to sustainable development goals in comparison with economic ones.
\end{abstract}

Keywords: Sustainable Development Goals, Agricultural Sector, State Policy, Assessment of the Effectiveness of State Policy, Ukraine.

\section{Introduction}

The basis for the formation and implementation of an effective policy is a high-quality comprehensive evaluation of government actions in previous periods. Such an evaluation should take into account the progress in achieving the set targets, the structural balance of the selected instruments and their impact on economic activity, which will ensure progress towards the UN Sustainable Development Goals. The uniqueness of the sustainable development goals is that they urge all countries - poor, rich and middleincome - to promote prosperity while protecting the planet $[\mathrm{X}]$.

The agricultural sector occupies an important place in modern post-industrial society. The agricultural sector is associated with such sustainable development goals as ensuring economic growth, food security, rational use of resources, the absence of poverty, increasing the incomes of employees, reducing inequality, rural development and preserving the environment.

The urgency and practical significance of the evaluation of state measures in the agricultural sector is evidenced by the EC Reports on the Results of the Agricultural Policy Union, the Reports of the Agencies 
included in the structure of the US Department of Agricultural Policy. Such reports are the basis for the development and implementation of state policy in the medium term.

The objectivity and reliability of conclusions on the effectiveness of state measures are ensured by the scientific validity of the chosen evaluation system.

\section{Statement of the Problem}

Economics has developed methodological techniques and methodological approaches to assessing state policy, which have theoretical and practical significance. In particular, we proposed a comprehensive evaluation of the effectiveness of the organizational and economic mechanism of regulatory policy in agriculture, which is carried out taking into account progress towards sustainable development goals, the achievement of which is related to agriculture, progress in institutional support of agriculture, measures and costs for conducting regulatory policy in the agricultural sector (Shibaeva et al. (2019)).

The chosen methodology is not static, it leaves space for further improvement by making quantitative and / or qualitative clarifications depending on the actualization of a specific goal, included in the sustainable development goals, time factor, modern scientific developments, completeness of the statistical base.

\section{Objective of the Study}

The purpose is to identify the opportunities of improving the evaluation of the effectiveness of regulatory policy in the agricultural sector by refining and testing the system of indicators included in the proposed comprehensive evaluation, in order to develop the methodological basis for research on the effectiveness of state influence on the agricultural sector.

\section{Research Hypothesis}

Evaluation of the effectiveness of state regulatory policy measures in the agriculture requires expanding the number of indicators through a group of social and environmental indicators.

\section{Literature Review}

The formation of a methodological basis for a comprehensive evaluation of the effectiveness of state policy, both to adjust and to optimize measures of state influence on the socio-economic processes, is a difficult task to solve which (or certain aspects) is aimed at a number of studies in recent years in Ukraine and abroad.

The research of Angilellaa et al. (2018) is dedicated to the evaluation of sustainable development in rural areas. The authors proposed a number of mathematical methods to solve the problem of taking into account a plurality of indicators and elicitation of the parameters for the composite indices. Such mathematical methods are the Robust Ordinal Regression (ROR), the Stochastic Multicriteria Acceptability Analysis (SMAA) and the Multiple Criteria Hierarchy Process (MCHP).

The results of the research project of Cattaneo et al. (2016) have defined the strategy system methods and selection of tools for the development of rural areas both in China and the EU. Priority methods, which allow defining the overall strategy of support actions for the development of rural areas both in China and the EU, are semantic analysis and a meta-project design.

Phuong T. Nguyen et al. (2019) pay attention to the necessity of identifying indicators for rural community in developing countries. The authors propose a set of principles, which improve the structural indicators of rural development. The positive impact of the framework reflects an increase to the communities' human and social capital.

The methodical approach how to define the indicators of sustainable development (including economic, socio-demographic, labor and environmental domains) of rural areas in Ukraine was proposed by Shcherbak et al. (2020). This approach is based on the consistent use of economic, mathematical and expert methods: SWOT-analysis, factor, cluster and discriminant analysis. The tracking model contains two scenarios of rural development: maximum and moderate and allows the determination of the sustainable development of different specialization branches of rural areas.

Nevertheless, the methodology of comprehensive (integrated) evaluation of state policy, which takes into account the effectiveness of state measures in the context of progress towards the sustainable development goals, has not become widespread yet. The evaluation of the state's measures in certain policy areas prevails, 
or the progress in achieving the goals of sustainable development is assessed separately. (Ministry for Development of Economy, Trade and Agriculture of Ukraine, (2020)).

Therefore, the research that contributes to the development and improvement of a methodology for comprehensive evaluation of the effectiveness of state policy is relevant.

\section{The main material}

The effectiveness of regulatory policy in the agricultural sector was evaluated as the object of the study. In understanding efficiency, we use the theory of management, according to which efficiency is measured by the degree of achievement by the organization the indicators that characterize the main objectives of its activities. Interpretation of efficiency in management theory does not preclude an economic understanding of this category as a comparison of the results obtained to the resources spent on their achievement. The main goal of the state in the economy is defined by the mainstream of economics as the maximization of social welfare. In modern conditions, the maximization of social welfare is embodied in the concept of sustainable development, the system of goals (indicators) which is a guide in the formation of state policy measures.

To assess the effectiveness of regulatory policy in the agricultural sector of Ukraine, we proposed the author's methodological approach (Shibaeva et al. (2019)). The features of our methodological approach are as follows. Efficiency is determined, firstly, by the progress in achieving the sustainable development goals, that are associated with the functioning of the agricultural sector. Secondly, it depends on the goals of state programs in the agricultural sector. Thirdly, the effectiveness of regulatory policy is identified by the progress in institutional support of regulatory policy. Fourthly, it is determined by the measures and costs of regulatory policy.

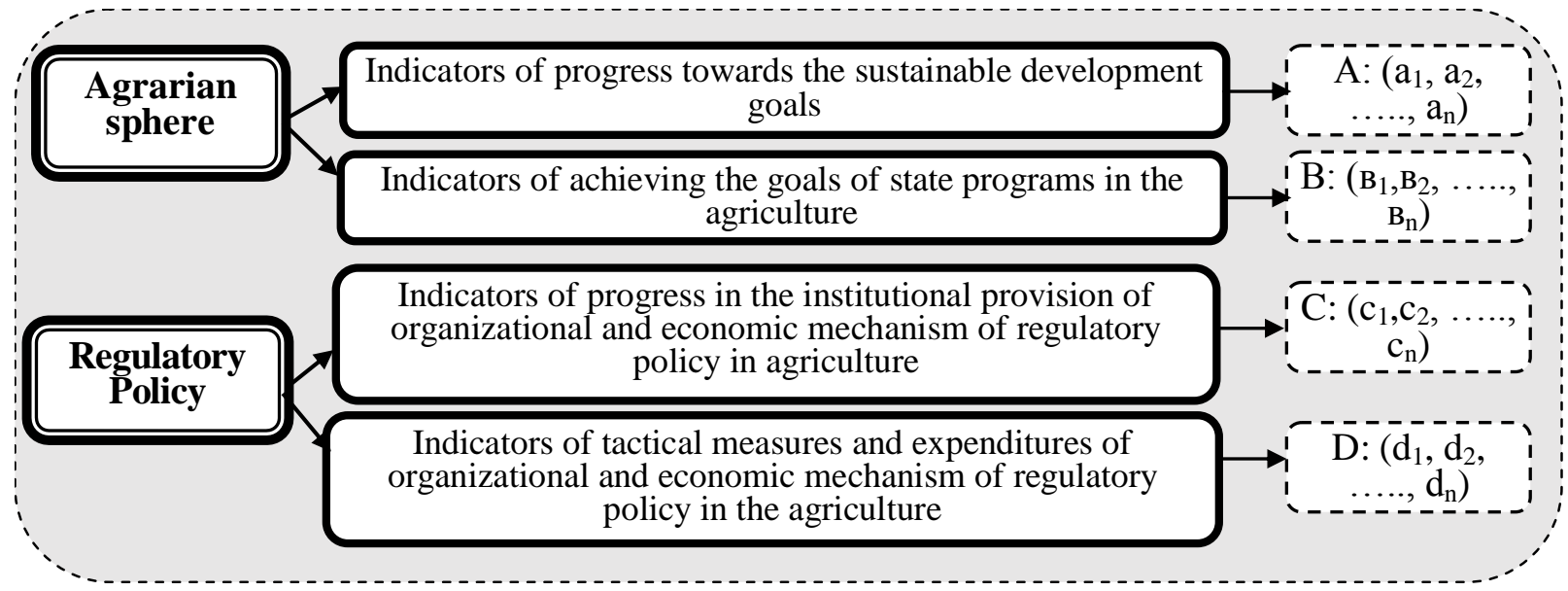

\section{Source: developed by the author}

\section{Fig. 3: The structure of the organizational and economic mechanism of regulatory policy effectiveness assessment indicators in agriculture}

Testing of the proposed methodological approach for a comprehensive evaluation of the effectiveness of the regulatory policy of Ukraine in the agricultural sector was carried out for 2010-2016, 2017. It allowed to draw conclusions about the slow progress in the effectiveness of the regulatory policy in the agricultural sector of Ukraine in the studied period.

Indicators of agricultural production volumes, resource efficiency demonstrate progress in achieving targets. The indicators of the population's nutrition structure, food affordability, salary level and poverty rate reflect an unsatisfactory state in achieving the relevant goals. An increase in investments in the agricultural sector and nominal volumes of loans granted, occurs even if high interest rates are maintained. Institutional support for the conditions for doing business in Ukraine is improving, the quality of public administration, at the same time, it is still not at a high level, decentralization processes are slow.

State expenditure on financing the agricultural sector has significant fluctuations. The volumes of state support for the agricultural sector and their coherence with medium-term programs require strengthening substantiation. Budget planning is designed for the short-term period (for 1 year). It reflects the results of the 
influence of the forces of the political market on the formation of the budget, and not its compliance with a reasonable medium-term development strategy. Indicators of state support according to the OECD methodology are negative (which indicates the net taxation of agricultural producers) and the smallest among countries for which the OECD calculates. The marginal volumes of support in accordance with WTO requirements are significantly lower than the level of agricultural support in the EU. The fiscal space of Ukraine does not allow supporting agriculture at the level determined by the requirements of the WTO. But indicators of agricultural support by the WTO methodology are important indicators for the development of budget programs, ensuring compliance with the regulatory policy of Ukraine's commitments.

The advantage of the proposed methodological approach is the possibility of a comprehensive evaluation of the effectiveness of regulatory policy in the direction of achieving the sustainable development goals. Another benefit is coherence and consistency between the goals and volumes of financing state programs in the agricultural sector, the creation and support of market institutions.

The advantage of the proposed methodological approach also involves the possibility of including more or less indicators in each of the four directions in assessing the effectiveness of the policy. The number of indicators may depend on the completeness and frequency of the statistical data of a particular research area, as well as on the tasks set for the researcher. The proposed methodology is applicable to assess the effectiveness of government policy in other areas of the economics.

We took into account the numerous modern developments on the issues of assessing the achievement of the sustainable development goals of the national economy, its individual areas, and rural territories. We consider it appropriate to specify a system of indicators in our proposed methodology that reflect progress in achieving the sustainable development goals of the agricultural sector.

It should be noted that there are difficulties associated with the features of the collection and processing of statistical information for the short and medium term. Such features make it impossible to use the proposed indicators to assess the effectiveness of policy in the short term. At the same time, we note that the formation and implementation of the regulatory policy and the economic policy of the state, in general, take place mainly for the short and medium term.

Another debatable point, from the point of view of the evaluating methodology, is the involvement of the state in the processes of economic development on the principles of sustainability. Economic science and the practice of state regulation are unanimous in that the role of the state as a catalyst for economic processes and the backbone of the institutional structure in the modern world is increasing. The costs associated with the implementation of economic policy are also increasing. Our methodology allows to consider these factors and, if necessary, adjust them.

We see the further development of the methodology for assessing the effectiveness of the state's regulatory policy in the agricultural sector in strengthening the environmental and social components. We propose strengthening the environmental component of the evaluation of the progress of sustainable development goals through the expansion of the relevant group of indicators of protection and restoration of ecosystems in the process of their agricultural use. We offer to include such indicators in the total area of agricultural land as: share of arable land; the share of areas treated with mineral fertilizers; the share of areas treated with organic fertilizers; the amount of nitrogen and phosphorus fertilizers per 1 ha of the specified sown area; environmental protection costs. We propose to strengthen the social component by including in the relevant group of functional indicators that reflect the tactical measures of regulatory policy and the cost of their implementation of the State programs to support housing in rural areas, social investment and own resources of local communities to create a comfortable environment.

The expedience of making the proposed clarifications, in our opinion, is due to the following. The concept of sustainable development also covers land use, which should be not only economically efficient, but also socially oriented and environmentally safe. The level of land use intensity affects the maintenance of the balance of organic matter and biological condition of the soil (determined by the humus content). Humus content indicators are published every five years as a part of land certification. Therefore, we consider it appropriate to take into account the indicators, the statistics of which are given every year, and which affect 
the biological condition of the soil and, accordingly, sustainable land use. They are the indicators of the structure of agricultural lands and annual amounts of mineral fertilizers.

Rational use of nature is characterized by the structure of agricultural land use. According to scientific recommendations, no more than a third of the territory should be involved in active agricultural cultivation. A third should be set aside for other economic activities, and a third should remain in a natural state that ensures ecological balance in nature (Fedorov M. (2009)). But in the structure of domestic agricultural lands, arable land occupies more than $70 \%$, which is much more than evidence-based standards. We believe that indicators of the structure of agricultural lands should be included in the evaluation of the effectiveness of state policy in the agricultural sector as a reflection of environmental balance and approximation to the environmental components of sustainable development.

The main measure aimed at enriching the soil with nutrients is the restoration of the annual volume of mineral fertilizers to the level of 150-160 kg / ha. Therefore, the amount of mineral fertilizers used should be taken into account when assessing progress in achieving the environmental components of sustainable development goals.

Strengthening the social component of indicators of progress in achieving sustainable development goals is appropriate. The appropriateness is due to the fact that per capita construction of housing, education, culture, sports, health, living, trade, gasification, water and electricity, communications, utilities in rural areas lag far behind urban settlements. To improve the situation in rural areas, state funding is needed, the amount of which we propose to take into account in the methodology for assessing the effectiveness of state measures in the agricultural sector.

We use the methodological approach of evaluation the effectiveness of state regulatory policy in the agricultural sector of Ukraine in 2010, 2016-2018 with the proposed clarifications. They strengthen the environmental and social component, and also take into account state funding of environmental and social development of agriculture. This approach is presented in table 1.

Table 1: Comprehensive assessment of the effectiveness of economic mechanism of regulatory policy of Ukraine in the agricultural sector in 2010, 2016-2018

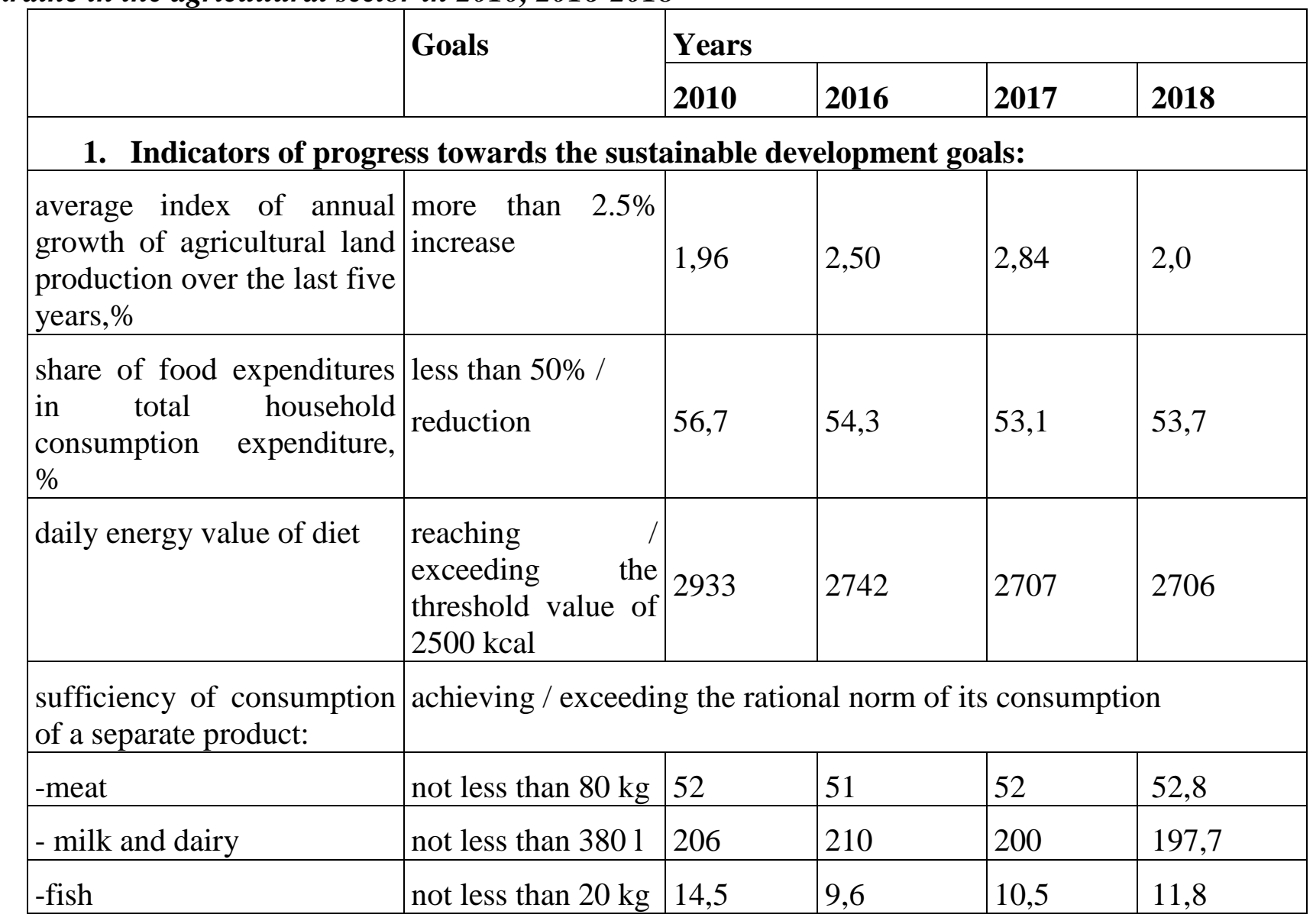




\begin{tabular}{|c|c|c|c|c|c|}
\hline - vegetables and squash & $\begin{array}{l}\text { not less than } 161 \\
\mathrm{~kg}\end{array}$ & 144 & 164 & 161 & 163,9 \\
\hline -fruit & not less than $90 \mathrm{~kg}$ & 48 & 50 & 54 & 57,8 \\
\hline $\begin{array}{l}\text { self-sufficiency, as the ratio } \\
\text { of domestic production of } \\
\text { the product per person to } \\
\text { the rational norms of its } \\
\text { consumption; }\end{array}$ & \multicolumn{5}{|c|}{ reaching / exceeding the rational norm of its consumption } \\
\hline -meat and meat products & not less than 1 & 0,56 & 0,68 & 0,69 & 0,70 \\
\hline -milk and dairy & not less than 1 & 0,65 & 0,64 & 0,64 & 0,63 \\
\hline -vegetables and squash & not less than 1 & 1,2 & 1,46 & 1,42 & 1,46 \\
\hline -fruit & not less than 1 & 0,52 & 0,62 & 0,65 & 0,80 \\
\hline $\begin{array}{l}\text { production of agricultural } \\
\text { products (at } \\
\text { prices), } \mathrm{UAH} \text { : } \\
\text {-on } 1 \text { ha of } \\
\text { land, }\end{array}$ & increase & 4687,5 & 6135,2 & 6005,3 & 6493,4 \\
\hline $\begin{array}{l}\text { Per the average employee, } \\
\text { in thousand UAH, at } \\
\text { constant prices }\end{array}$ & increase & 72,6 & $275, .3$ & 271,5 & 313,6 \\
\hline $\begin{array}{l}\text { per } 1 \text { UAH of current and } \\
\text { non-current assets }\end{array}$ & Increase & 0,9 & 0,2 & 0,32 & 0,6 \\
\hline $\begin{array}{l}\text { average monthly salary in } \\
\text { agriculture, UAH }\end{array}$ & increase & 1472 & 4195 & 6057 & 7557 \\
\hline $\begin{array}{l}\text { the ratio of the average } \\
\text { monthly wage to its level in } \\
\text { the economy in general }\end{array}$ & $\begin{array}{l}\text { increase / not less } \\
\text { than } 1\end{array}$ & 0,66 & 0,81 & 0,85 & 0,85 \\
\hline $\begin{array}{l}\text { Poverty rate in rural areas } \\
\text { (share of population with } \\
\text { per capita equivalent } \\
\text { cumulative incomes below } \\
\text { the living wage (estimated), } \\
\%\end{array}$ & decrease & $\begin{array}{l}20 \text { (to the } \\
\text { statutory } \\
\text { minimum } \\
\text { wage) }\end{array}$ & 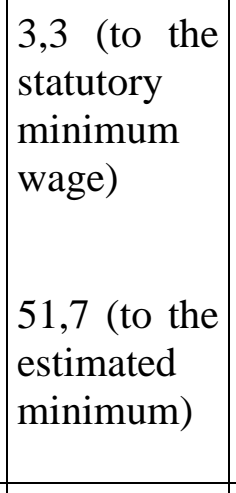 & 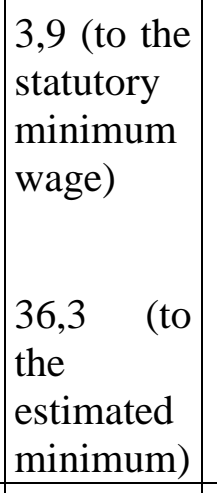 & 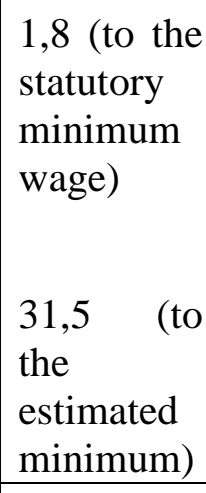 \\
\hline $\begin{array}{l}\text { rural settlements } \begin{array}{r}\text { with } \\
\text { pavement and } \\
\text { lighting }\end{array} \\
\end{array}$ & Increase & - & $\begin{array}{l}47,8 \% \text { and } \\
22 \%\end{array}$ & - & - \\
\hline 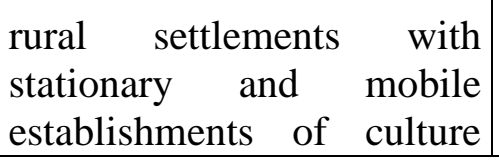 & Increase & - & $\begin{array}{l}\text { less than } \\
50 \%\end{array}$ & $\begin{array}{ll}\text { less } & \text { than } \\
50 \% & \end{array}$ & $\begin{array}{l}\text { less than } \\
50 \%\end{array}$ \\
\hline
\end{tabular}




\begin{tabular}{|c|c|c|c|c|c|}
\hline and service & & & & & \\
\hline $\begin{array}{l}\text { The amount of humus in the } \\
\text { soil, } \% \\
\text { calculation once every } 5 \\
\text { years }\end{array}$ & $\begin{array}{l}\text { compliance with } \\
\text { the requirements } \\
\text { of DSTU } \\
4362: 2004 \\
\text { DSTU 7923:2015 / } \\
\text { increase }\end{array}$ & 3,2 & $\begin{array}{l}3,14 \text { the } \\
\text { negative } \\
\text { balance on } \\
\text { average for } \\
\text { the year is } \\
110-130 \\
\mathrm{~kg} / \mathrm{ha})\end{array}$ & 3,14 & 3,14 \\
\hline $\begin{array}{l}\text { The share of areas treated } \\
\text { with mineral fertilizers to the } \\
\text { total area of agriculture } \\
\text { lands, } \%\end{array}$ & Increase & 30,5 & 37,8 & 39,8 & 38,8 \\
\hline $\begin{array}{l}\text { The share of areas treated } \\
\text { with organic fertilizers to the } \\
\text { total area of agriculture } \\
\text { lands, } \%\end{array}$ & Increase & 1,0 & 1,2 & 1,2 & 1,9 \\
\hline $\begin{array}{l}\text { The share of arable land in } \\
\text { the total area of agriculture } \\
\text { lands, } \%\end{array}$ & $\begin{array}{l}\text { reduction to } \\
\text { optimal indicators } \\
\mid 40-45 \%\end{array}$ & 78,1 & 78,4 & 78,4 & 78,7 \\
\hline $\begin{array}{l}\text { Volume of nitrogen and } \\
\text { phosphorus fertilizers on } 1 \mathrm{ha} \\
\text { of the specified sown area, } \mathrm{kg}\end{array}$ & $\begin{array}{l}\text { increase to a } \\
\text { scientifically } \\
\text { sound norm } \\
150-160 \mathrm{~kg}\end{array}$ & 52,0 & 83,0 & 94,0 & 102,0 \\
\hline $\begin{array}{l}\text { Expenditures on } \\
\text { environmental protection in } \\
\text { agriculture, million UAH }\end{array}$ & Increase & 96,2 & 367,1 & 428,9 & 418,1 \\
\hline \multicolumn{6}{|c|}{ 2. Indicators of achieving the goals of state programs in the agriculture } \\
\hline $\begin{array}{l}\text { investments in agriculture, } \\
\text { UAH million, actual prices }\end{array}$ & Increase & 11568 & 50484 & 64243 & 66104 \\
\hline Loan amount, million UAH & Increase & 26500 & 55100 & 59700 & 67675 \\
\hline Loan cost, \% & Reduction & 13,7 & 18,4 & 18,3 & 18,5 \\
\hline $\begin{array}{l}\text { Number of leased } \\
\text { machinery }\end{array}$ & Increase & 352 & - & 1100 & $\begin{array}{l}669 \text { in the } \\
\text { half of a } \\
\text { year }\end{array}$ \\
\hline $\begin{array}{l}\text { Number of machinery, } \\
\text { thousand }\end{array}$ & Increase & 151,3 & 132,7 & 129,3 & 129,3 \\
\hline $\begin{array}{l}\text { Tractors, pieces per } 100 \text { ha } \\
\text { of arable land }\end{array}$ & $\begin{array}{l}\text { increase / reach the } \\
\text { EU average }\end{array}$ & 0,47 & 0,41 & 0,36 & 0,36 \\
\hline $\begin{array}{l}\text { combine harvesters, pieces } \\
\text { per } 100 \text { ha of grain crops }\end{array}$ & $\begin{array}{l}\text { increase } \\
\text { achievement of the } \\
\text { EU average }\end{array}$ & 0,36 & 0,38 & 0,38 & 0,38 \\
\hline $\begin{array}{l}\text { Average power of the } \\
\text { tractor engine, } \mathrm{kW}\end{array}$ & Increase & 83,0 & 95,1 & 97,3 & 97,3 \\
\hline
\end{tabular}




\begin{tabular}{|l|l|l|l|l|l|}
\hline livestock (cattle), thousands & Increase & 4494,4 & 3682,3 & 3530,8 & 3332,9 \\
\hline pigs, thousand & Increase & 7960,4 & 6669,1 & 6109,9 & 6025,3 \\
\hline poultry, thousand & Increase & 203839,8 & 201668,0 & 204830,9 & 211654,4 \\
\hline $\begin{array}{l}\text { Agricultural livestock } \\
\text { performance, including } \\
\text { average annual milk yield, } \\
\text { kg / head Increase }\end{array}$ & 4082 & 4735 & 4820 & 4922 \\
\hline $\begin{array}{l}\text { volumes of agricultural } \\
\text { production by farms (at } \\
\text { constant prices), UAH } \\
\text { million Increase }\end{array}$ & 11965,8 & 22101,4 & 21743,1 & 25118,9 \\
\hline
\end{tabular}

3. Indicators of progress in the institutional provision of organizational and economic mechanism of regulatory policy in agriculture

\begin{tabular}{|c|c|c|c|c|c|}
\hline \begin{tabular}{|l} 
Ranking \\
Business"
\end{tabular} & $\begin{array}{l}\text { Joining the top } 20 \\
\text { countries in terms } \\
\text { of doing business }\end{array}$ & 142 & 83 & 80 & 76 \\
\hline 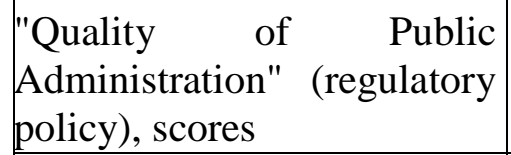 & increase & 33,0 & 36,1 & 40,4 & 44,23 \\
\hline $\begin{array}{l}\text { the share of expenditures of } \\
\text { the State and local budgets } \\
\text { on the agriculture in the } \\
\text { Consolidated Budget of } \\
\text { Ukraine, } \%\end{array}$ & $\begin{array}{l}\text { increasing the } \\
\text { share of } \\
\text { expenditures of } \\
\text { local governments, } \\
\text { local executive } \\
\text { authorities }\end{array}$ & $\begin{array}{l}98 \% \\
(\text { state }) \\
2 \% \text { (local) }\end{array}$ & $\begin{array}{l}76 \% \text { (state) } \\
24 \% \text { (local) }\end{array}$ & $\begin{array}{l}85 \% \\
\text { (state) } \\
15 \% \\
\text { (local) }\end{array}$ & 97,5 \\
\hline \multicolumn{5}{|c|}{$\begin{array}{l}\text { 4. Indicators of tactical measures and expenditures of organizational and } \\
\text { economic mechanism of regulatory policy in the agriculture }\end{array}$} & \\
\hline $\begin{array}{l}\text { state expenditures on } \\
\text { agriculture, UAH million }\end{array}$ & $\begin{array}{l}\text { compliance with } \\
\text { the identified } \\
\text { need / plan }\end{array}$ & 7339,0 & 1638,3 & 10289,9 & 13041,9 \\
\hline $\begin{array}{l}\text { direct state support for } \\
\text { agriculture producers, UAH } \\
\text { million }\end{array}$ & $\begin{array}{l}\text { compliance with } \\
\text { the identified } \\
\text { need / plan }\end{array}$ & 364,2 & 420,0 & 5430,7 & 6807,1 \\
\hline $\begin{array}{l}\text { state support of the } \\
\text { agriculture } \\
\text { methodology) }\end{array}$ & $\begin{array}{l}\text { compliance with } \\
\text { a certain level }\end{array}$ & $\begin{array}{l}\mathrm{PSE}= \\
5,6 \% \\
\mathrm{TSE}= \\
1,74 \%\end{array}$ & $\begin{array}{l}\mathrm{PSE}= \\
-3,0 \% \\
\mathrm{TSE}= \\
-0,75 \%\end{array}$ & $\begin{array}{l}\mathrm{PSE}= \\
-2,8 \% \\
\mathrm{TSE}= \\
-0,6 \%\end{array}$ & $\begin{array}{l}\mathrm{PSE}= \\
-0,7 \% \\
\mathrm{TSE}= \\
-0,01 \%\end{array}$ \\
\hline $\begin{array}{l}\text { state support in the context } \\
\text { of the WTO "boxes" }\end{array}$ & $\begin{array}{l}\text { compliance with } \\
\text { WTO obligations } \\
*\end{array}$ & $\begin{array}{l}\text { compliance } \\
\text { with } \\
\text { obligations }\end{array}$ & $\begin{array}{l}\text { compliance } \\
\text { with } \\
\text { obligations }\end{array}$ & \begin{tabular}{|lr} 
complianc \\
e r with \\
obligation \\
s
\end{tabular} & $\begin{array}{l}\text { complianc } \\
\text { e with } \\
\text { obligation }\end{array}$ \\
\hline State programs to support & Increase & & 40,0 & 40,0 & 37,5 \\
\hline
\end{tabular}




\begin{tabular}{|l|l|l|l|l|l|}
\hline $\begin{array}{l}\text { housing construction in rural } \\
\text { areas, UAH million }\end{array}$ & & & & \\
\hline $\begin{array}{l}\text { Investments and own } \\
\text { community resources for the } \\
\text { improvement of rural } \\
\text { settlements, UAH million }\end{array}$ & & 8,6 & 1000,0 & 500,0 & 1900,0 \\
\hline
\end{tabular}

* UAH 3 billion 43 million additionally, Ukraine can spend up to 5\% of the annual value of gross agricultural output and up to $5 \%$ of its annual value on each individual product for "yellow" non-product programs.

Evaluation of the effectiveness of regulatory policy in the agricultural sector of Ukraine during 2010, 20162018 has an expanded system of indicators. They reveal the progress of environmental and social components in achieving sustainable development goals, as well as take into account state funding of environmental and social development of the agricultural sector, which was managed not only by the Ministry of Agricultural Policy, but also by other ministries. Evaluation of the effectiveness reflects the persistence of slow progress in the effectiveness of regulatory policy in the agricultural sector, the backlog of social and environmental indicators in the approach to sustainable development goals in comparison with economic ones.

\section{Discussion and Finding}

The results and conclusions of the study are reliable given that the basis for obtaining them are the data of official statistics of Ukraine and international institutions.

The expansion of the system of indicators in evaluation of the effectiveness of the regulatory state policy in the Ukrainian agriculture contributes to the objectivity of the results. Improving the methodology for evaluation of state measures in this way emphasizes the importance of social and environmental components of sustainable development of agriculture.

The results of the study show a significant backlog of social and environmental indicators in approaching the sustainable development goals in comparison with economic ones.

Design of this study reflects, how the use of appropriate indicators can improve the methodology for evaluation of the effectiveness of regulatory policy in the agriculture.

The regulatory state policy is aimed at achieving short-term goals, which shows the progress in achieving the sustainable development goals in the economic component. The long-term goals of the state's regulatory policy should take into account the social and environmental components of sustainable development, but in modern conditions short-term goals are preferred. Achieving economic goals of sustainable development is important, and the state should determine a system of measures (programs and amounts of funding) to stimulate and support the agriculture, taking into account the importance of social and environmental components of sustainable development.

Research on the effectiveness of state regulatory policy, aimed at supporting the agriculture, mainly evaluate the economic functioning of the agriculture.

This article offers to improve the methodology of comprehensive evaluation of state policy in the agriculture for the first time.

The main economic indicators (volumes of agricultural products, investments, loans, efficiency of labor resources), indicators of food structure, economic affordability of food, the level of wages maintain the dynamics of previous periods.

Rural poverty is reducing, but the quality of life in rural areas does not show progress towards sustainable development goals.

The actual structure of agricultural land does not meet the optimal environmental parameters, the level of plowing is twice as high, the amount of mineral fertilizers increases, but does not reach evidence-based standards. 
The situation with land use indicates a high level of development and load on the agricultural soil, which increases the likelihood of threats of erosion and degradation of the country's land fund.

There is a further improvement of the institutional provision of business conditions in Ukraine, the quality of public administration, at the same time its level is not sufficient yet, decentralization processes have slowed down.

State expenditures on financing the agricultural sector fluctuate significantly and are inconsistent with medium-term development programs, budget planning remains short-term and is influenced by political factors. Financing of the social sphere in rural areas does not meet the legally defined indicators of $0.5 \%$ of Ukraine's GDP (Legislation of Ukraine, (2018)).

Indicators of state support according to the OECD methodology remain negative. But negative values reached a minimum for the period under study. It indicates a decrease in net tax burden on agricultural producers, which occurred not due to increased state support, but as a result of a favorable situation for Ukrainian farmers on the world market).

Ukraine's budgetary capabilities in 2018 did not allow maintaining agriculture at the level set by WTO requirements.

\section{Implication of Finding}

There was the slow progress in the effectiveness of regulatory policy in the agricultural sector in Ukraine in 2010, 2016-2018. It was due to the lack of focused, planned change management, medium-term planning, declarative nature of government programs, imperfect financial instruments to support the agricultural sector and their application. The formation and implementation of a medium-term strategy based on the principles of stability, certainty and transparency of the state's regulatory influence on economic conditions will increase the effectiveness of the state's regulatory policy in the agricultural sector and harmonize its focus on sustainable development goals.

The principle of cross-compliance, as a mandatory requirement in relations between the state and agricultural producers, will ensure optimization of the structure of agricultural landscapes. Also it will promote improving the structure of sown areas and crop rotations in order to maintain the optimal balance of organic matter and biological condition of the soil; the application of soil-protective energy-saving technologies of land cultivation.

\section{Conclusion}

Evaluating the effectiveness of state measures in previous periods is the basis for the formation and implementation of state policy for subsequent periods. Such an evaluation should be comprehensive and take into account the progress towards the targets, the structural balance of the instruments chosen and their impact on economic activity, which will ensure progress towards the UN Sustainable Development Goals.

The comprehensiveness of the evaluation is provided by our chosen methodological basis. It allows to determine progress in approaching the sustainable development goals, achieving the goals of state programs in the agricultural sector, improving the institutional support of public policy, take into account the costs of its implementation.

One of the ways to improve the evaluation of the effectiveness of regulatory policy in the agricultural sector is to clarify the system of environmental and social indicators included in the proposed methodological basis. We expanded the group of environmental indicators. Also we took into account other state sources of funding for social programs of rural development and tested an improved system for assessing the effectiveness of state policy in the agricultural sector of Ukraine in 2010, 2016-2018.

The expansion of the system of indicators allowed to specify the relationship between economic, environmental, social indicators and measures of the state to stimulate the development of Ukraine's agricultural sector and its approach to sustainable development goals. Significant backlog of environmental and social indicators in approaching the sustainable development goals in comparison with economic ones was identified. 


\section{Recommendations}

The environmental validity of agricultural activities, the economic feasibility of using land for various purposes has to ensure progress in the approximation of environmental indicators to the sustainable development goals. The progress in approximation of social indicators is ensured on the assumption of the actual state expenditures on rural financing correspond to the fact that they are defined by the law.

The main measures for this should be: approval of the practice of medium-term programming, implementation and enforcement of cross-compliance, mandatory and accessible reports on the results of government programs, financial support for rural development.

\section{References}

[1.] Angilellaa, S.; Catalfoa, P.; Correntea, S.; Giarlottaa, A.; Grecoa, S.; Rizzoa, M. (2018) Robust sustainable development assessment with composite indices aggregating interacting dimensions: the hierarchical-SMAA-Choquet integral approach. Knowledge-Based Systems. 158: 136-153.

[2.] Cattaneo, T.; Giorgi, E.; Ni, M. Giorgio, D., (2016). Sustainable development of rural areas in the EU and China: a common strategy for architectural design, research practice and decision-making. Buildings. 6(4): 1-22.

[3.] Fedorov M. (2009). Transformation of land relations to market conditions. Economics of AIC., 3: 4-18. http://www.ukrstat.gov.ua/druk/publicat/kat_u/2019/zb/09/Zb_sg_2018\%20.pdf

[4.] Legislation of Ukraine, (2011). Some issues of food security: Resolution of the Cabinet of Ministers of Ukraine. https://zakon.rada.gov.ua/laws/show/1379-2007-\%D0\%BF?lang=en

[5.] Legislation of Ukraine, (2018). On the priority of social development of the village and agroindustrial complex in the national economy. https://zakon.rada.gov.ua/laws/show/400-12\#Text

[6.] Ministry for Development of Economy, Trade and Agriculture of Ukraine, (2020). Sustainable Development Goals. https://www.me.gov.ua/Documents/List?lang=uk-UA\&id=938d9df1-5e8d48cc-a007-be5bc60123b8\&tag=TSiliStalogoRozvitku

[7.] Phuong T. Nguyen; Sam Wells; Nam Nguyen. (2019). A Systemic Indicators Framework for Sustainable Rural Community Development. Syst Pract Action Res. 32: 335-352.

[8.] Shcherbak, V.; Ganushchak-Yefimenko, L.; Nifatova, O.; Fastovets, N.; Plysenko, H.; Lutay, L.; Tkachuk, V.; Ptashchenko, O., (2020). Use of key indicators to monitor sustainable development of rural areas. Global J. Environ. Sci. Manage., 6(2): 175-190.

[9.] Shibaeva, N.; Baban, T.; Prokhorova, V.; Karlova, O.; Girzheva, O.; Krutko, M., (2019). Methodological bases of estimating the efficiency of organizational and economic mechanism of regulatory policy in agriculture. Global. J. Environ. Sci. Manage., 5(SI): 160-171. DOI: 10.22034/gjesm.2019.SI.18

[10.] State Statistics Service of Ukraine, (2018). Agriculture of Ukraine.

[11.] United Nations - Disability, (2015). Envision 2030: 17 goals to transform the world for persons with disabilities. https://www.un.org/development/desa/disabilities/envision2030.html

[12.] United Nations Ukraine, (2017). National Baseline report: Sustainable development goals: Ukraine. http://www.un.org.ua/en/publications-and-reports/un-in-ukraine-publications/4205-2017national-baseline-report-sustainable-development-goals-ukraine 